\title{
Monitoring Prunus Necrotic Ringspot Virus Infection by Hybridization with a cRNA Probe after in vitro Micrografting
}

\author{
Kathleen Heuss-LaRosa', Rosemarie Hammond ${ }^{2}$, James M. Crosslin ${ }^{1,3}$, Christine Hazel', and \\ Freddi A. Hammerschlag ${ }^{1,4}$ \\ U.S. Department of Agriculture, Agricultural Research Service, Beltsville, MD 20705-2350
}

Additional index words. Prunus persica, tissue culture

\begin{abstract}
In vitro micrografting was tested as a technique for inoculating peach [Prunus persica (L.) Batsch] shoot cultures with Prunus necrotic ringspot virus (PNRSV). Cultured 'Suncrest' shoots derived from a naturally infected tree (as indicated by ELISA testing) maintained virus in vitro, with virus concentrations in growing tips and folded leaves being several times those of fully expanded leaves. Infected shoots served as graft bases and source of the virus. Grafted tips were derived from 'Suncrest' trees that had tested negative for the virus. Leaf samples were collected from the tips following grafting and analyzed for the presence of virus by slot-blot hybridization with a (DIG)-labeled cRNA probe derived from PNRSV RNA 3. Rates of successful grafting ranged from $55 \%$ to $73 \%$ in three trials and PNRSV was found in all tips analyzed. Virus concentrations approximated those found in source shoots, suggesting that in vitro micrografting should be useful for screening transformed peach shoots for coat protein-mediated resistance to PNRSV. Chemical name used: digoxigenin (DIG).
\end{abstract}

Prunus necrotic ringspot virus (PNRSV), a pollen-spread ilarvirus common in Prunus species, can cause substantial reductions in the growth and yield of peach (Pine, 1964; Schmitt et al., 1977; Topchiiska, 1982; Uyemoto et al., 1992; Wells et al., 1986). Control of this disease by planting virus-free stock and removal of ELISA-positive trees has been applied to peach (Scott et al., 1986). However, experience with a similar practice in cherry orchards suggests that its effectiveness could be hindered by the inability of available ELISA tests to distinguish severe strains of PNRSV from symptomless strains which cause little damage and which might possibly protect from more severe disease (Mink, 1992).

Another possible control strategy is the development of virusresistant peach cultivars through genetic engineering. Several modes of virus resistance are emerging based on transformation of plants with portions of viral genomes (Hull and Davies, 1992; Wilson, 1993). We plan to develop constructs containing the PNRSV coat protein gene under promoters suitable for expression in transgenic peach tissue, to exploit a strategy that has already been shown to be effective in producing resistance to several types of plant viruses including the ilarvirus group (Hull and Davies, 1992; van Dun et al., 1988).

Development of transgenic peaches with resistance to PNRSV will require a reliable method of screening for resistance. Resistance to PNRSV has been tested by bud-grafting infected tissue onto greenhouse trees (Wells et al;, 1986), but such testing is limited to those months of the year when peach tissues are actively growing (Nyland et al., 1974). However, in tissue-cultured shoots the dormancy period is replaced by a period of several weeks at $4 \mathrm{C}$ in the dark, which can be timed so as to provide actively growing plant material year-round. In vitro micrografting (Alskief, 1977; Murashige et al., 1972), has been used to produce virus-free cultures of peach (Mosella et al., 1980; Navarro et al., 1982). In this study, we describe

Received for publication 13 Feb. 1995. Accepted for publication 16 May 1995. The cost of publishing this paper was defrayed in part by the payment of page charges. Under postal regulations, this paper therefore must be hereby marked advertisement solely to indicate this fact.

'Plant Molecular Biology Laboratory.

${ }^{2}$ Molecular Plant Pathology Laboratory

${ }^{3}$ Current Address: USDA/ARS IAREC, Rt. 2, Box 2953A, Prosser, WA 00350.

${ }^{4}$ To whom reprint requests should be addressed. the use of in vitro micrografting as an inoculation method for tissuecultured peach shoots and present a preliminary study on the accumulation of PNRSV in peach shoot cultures following grafting. Because PNRSV-infected peach does not always show symptoms, we used nucleic acid hybridization with a virus-derived cRNA probe (Crosslin et al., 1992) to detect virus infection.

\section{Materials and Methods}

Plant material. Peach shoot cultures were initiated as described by Hammerschlag (1982) from shoots collected in 1990 from field-grown 'Suncrest trees' that had tested negative and from shoots collected during June and July 1993 from a cv. Suncrest tree that had tested positive for PNRSV by enzyme-linked immunosorbent assay (ELISA) (Crosslin et al., 1992). Shoots were maintained at $26 \mathrm{C}$ on an elongation medium containing Murashige and Skoog (MS) salts (Murashige and Skoog, 1962) supplemented with $0.05 \mu \mathrm{M}$ indole-3-butyric acid $0.88 \mu \mathrm{M}$ 6-benzyladenine, $2 \%$ (w/v) sucrose, $0.6 \%$ (w/v) Phytagar (GIBCO BRL, Grand Island, N.Y.) and in mg/liter: 0.4 thiamine $\mathrm{HCl}, 0.5$ pyridoxine $\mathrm{HCl}, 0.5$ nicotinic acid, 100 myo-inositol, and 0.1 p-aminobenzoic acid (elongation medium). Shoots were transferred to fresh elongation medium every 2 to 3 weeks. Shoots were tested for the presence of PNRSV as described below.

PNRSV localization in source shoots. After culture establishment, three shoots were selected to determine virus distribution within shoots. Newly formed peach leaves emerge folded longitudinally and unfold as they expand. The following samples were collected: a leaf near the top of the stem (lowest folded leaf), the apical shoot tip above this leaf, one leaf each from the middle and bottom of the stem, and one axillary shoot tip. Because transfer regimen (Reinert, 1966) and hormone levels (Loebenstein et al., 1980) can affect virus replication, sometimes leading to loss of the virus from cultures (Reinert, 1966), we monitored virus concentration over time in nine different shoots by collecting both a young (the lowest folded) and an older leaf (taken from the middle of the stem) at 2-week intervals starting 8 weeks after culture initiation. Samples were processed as described below.

Micrografting procedure. PNRSV-infected shoots were cultured for 5 to 6 months, then placed on a medium containing $0.3 \%$ 
(w/v) sucrose, $0.6 \%$ (w/v) Phytagar (GIBCO), and one halfstrength MS salts and incubated at $4 \mathrm{C}$ in the dark for 7 to 12 weeks. Shoots were removed from the cold 3 weeks before micrografting and placed on elongation medium and transferred again to fresh medium 1 week before micrografting. PNRSV-infected shoots were dissected to $2 \mathrm{~cm}$ in length, the shoot tip and axillary shoots removed, and a 2-mm longitudinal cut was made in the stem, $2 \mathrm{~mm}$ from the top cut surface. Shoot tips from uninfected shoots were dissected to $2 \mathrm{~mm}$ in length, two diagonal cuts were made at the base to form a wedge and the tip was inserted into the cut on the infected stem Micrografts were placed on fresh elongation medium and a sample of one or two young leaves was collected from the unused portion of the infected and uninfected shoots. Micrografts were transferred to fresh elongation medium every 2 weeks and axillary shoots were removed weekly from bases. Samples of total fresh weight 3 to $10 \mathrm{mg}$ (lowest folded leaf and/or the leaf immediately below) were collected from the grafted tips every 2 weeks at the time of transfer to fresh media, through 6 weeks after grafting. The grafting experiment was replicated three times with 20-26 grafts per treatment.

Viral RNA detection. All samples were processed immediately through the phenol-chloroform extraction and ethanol-acetate precipitation steps as described by Crosslin et al. (1992). Samples were resuspended in denaturing buffer $(8 \times \mathrm{SSC}, 10 \%$ formaldehyde; $1 \times \mathrm{SSC}=0.15 \mathrm{M} \mathrm{NaCl}, 0.015 \mathrm{~m} \mathrm{Na}$ citrate $\mathrm{pH} 7$ ) and 3 -fold or IO-fold serial dilutions made in $4 \times \mathrm{SSC}, 5 \%$ formaldehyde were applied to positively charged nylon membranes (BoehringerMannheim, Indianapolis), using a Bio-Dot SF apparatus (Bio-Rad, Richmond, Calif.). Unless otherwise indicated, buffers were made with reagents from Sigma (St. Louis). The entire sample set from a single shoot or graft was applied to a single membrane, along with an extract of leaf tissue from an uninfected cultured shoot which served as a negative control. A positive control consisting of a total RNA preparation from PNRSV (PE5 strain)-inoculated Chenopodium quinoa was also applied.

Blots were hybridized to a cRNA probe derived from a fragment of PE5 strain RNA 3 (Crosslin et al., 1992) which spans portions of both open reading frames (Hammond and Crosslin, 1995). This was synthesized as described, except that the nucleotide triphosphate mixture contained (DIG)-labeled uridine triphosphate (Boehringer-Mannheim) rather than ${ }^{32} \mathrm{P}$-labeled uridine triphosphate. Hybridizations were carried out at $68 \mathrm{C}$ as recommended by Boehringer-Mannheim in a buffer containing $50 \%$ deionized formamide, 5× SSC, $1 \%$ Genius System Blocking Reagent (Boehringer-Mannheim), 0.05\% sodium lauroyl sarcosine. $0.01 \%$ sodium dodecyl sulfate (SDS). Prehybridization was in the same buffer plus 3\% SDS. Post-hybridization as described by Crosslin et al. (1992) was followedby a wash in a blocking solution (2\% Genius System Blocking Reagent in $100 \mathrm{~mm}$ maleate, $150 \mathrm{~mm}$ $\mathrm{NaCl} \mathrm{pH} 7.5$ ), a single wash in blocking solution containing 0.15 $\mathrm{U} / \mathrm{ml}$ anti-DIG antibody linked to alkaline phosphatase (BoehringerMannheim), and two washes in maleate- $\mathrm{NaCl}$ buffer alone. After a final wash in $0.1 \mathrm{~m}$ Tris $\mathrm{HCl}$ buffer $\mathrm{pH} 9.5$ containing $100 \mathrm{~mm}$ $\mathrm{NaCl}$ and $50 \mathrm{~mm} \mathrm{MgCl}$, membranes were incubated with Lumiphos 530 (Boehringer-Mannheim) and exposed to Amersham MPHyperfilm. Films were analyzed by densitometry with an LKB UltroScan XL (using the linear beam) and integration with the LKB 2400 GelScan XL software package. Values for area under the absorbance peak divided by the amount of extract applied were in good agreement for all dilutions of a particular sample, provided that the area under the peak was 1.0 absorbance unit or less. Therefore all dilutions having a peak area of 1.0 or less were averaged for each sample.
Statistical analysis. Virus concentrations at different sampling periods in the graft-inoculation experiment were compared using Analysis of Variance.

\section{Results}

PNRSV localization in source shoots. Shoot cultures derived from the PNRSV-infected tree grew well and showed no obvious differences in appearance compared to shoots from uninfected trees. Of 166 shoots that survived after culture initiation, 165 tested positive for PNRSV by the RNA hybridization assay. Samples from shoots derived from negative-testing trees did not react with the cRNA probe. Virus concentration was higher in the young (folded) leaves and in the apical and axillary tips (Fig. 1), the concentrations in these tissues being lo-fold or more higher than in the middle and lower leaves, as judged by visual comparison of different dilutions on the film. Similarly, when virus concentrations were followed over time in the lowest folded and in middle leaves (Fig. 2), higher concentrations were always found in younger leaves. The ratio of virus concentrations in younger to concentrations in older leaves increased from 5.8- to 27-fold over time (Table 1). When the change in virus concentration over time was analyzed separately for older or younger leaves (Table 1), it was found that the virus concentration in younger leaves tended to increase while concentrations in older leaves were constant.

Graft inoculations. Successful grafting, as judged by growth of grafted tips to sufficient size for sampling, occurred within 2 weeks at rates of $55 \%, 71 \%$, and $73 \%$, respectively for the three replicate grafting experiments. Tips sampled at this time were 0.3 to $1.5 \mathrm{~cm}$ long with five to 12 leaves. A few additional grafts began growing by 4 weeks. In successful grafts, total growth of tips by 6 weeks was 1 to $6 \mathrm{~cm}$.

Four grafts for which samples had been taken at all three sampling periods were randomly selected from each replication for further sample processing and analysis of virus concentration by RNA hybridization. All shoot cultures derived from the PNRSVinfected tree and used for grafting contained detectable levels of virus, while all shoots used for graft tips tested negative for PNRSV. Virus was present in tips by 2 weeks after grafting and shoots remained infected through 6 weeks in all grafts analyzed (Fig. 3). At 2 weeks after grafting, the average virus concentration in leaf samples from grafted tips was nearly three times that found in leaves from the infected base, but by 4 weeks the concentration dropped to a level close to that in the infected base (Fig. 3). The average virus concentration at 2 weeks differed significantly $(0.05$ level of significance) from averages at 4 and 6 weeks after grafting.

Table 1. Average relative concentrations of Prunus necrotic ringspot virus in peach leaves.

\begin{tabular}{|c|c|c|c|}
\hline \multirow{2}{*}{$\begin{array}{l}\text { Sampling } \\
\text { period }\end{array}$} & \multicolumn{2}{|c|}{ Relative virus concn } & \multirow{2}{*}{$\frac{\text { Ratio }^{y}}{\text { (Younger : older) }}$} \\
\hline & Younger leaves & Older leaves & \\
\hline 1 & $7.4 \pm 0.9$ & $1.20 \pm 0.20$ & $5.8: 1$ \\
\hline 2 & $11.8 \pm 1.0$ & $0.82 \pm 0.11$ & $14.6: 1$ \\
\hline 3 & $22.4 \pm 6.1$ & $0.94 \pm 0.10$ & 27.7: 1 \\
\hline
\end{tabular}

${ }^{\overline{2}}$ Values are the averages ( $\pm \mathrm{SE}$ ) for either younger (lowest folded) or older (expanded) leaves from nine shoots sampled three times at 2-week intervals. For each leaf and sampling period a relative virus concentration was calculated by dividing the absorbance peak area/mg by the mean absorbance peak area/mg over all sampling periods for older leaves of the same shoot. The relative values for each sampling period were then averaged over all shoots.

'Ratio of concentrations was calculated within each shoot, then averaged over all shoots. 


\subsection{1}

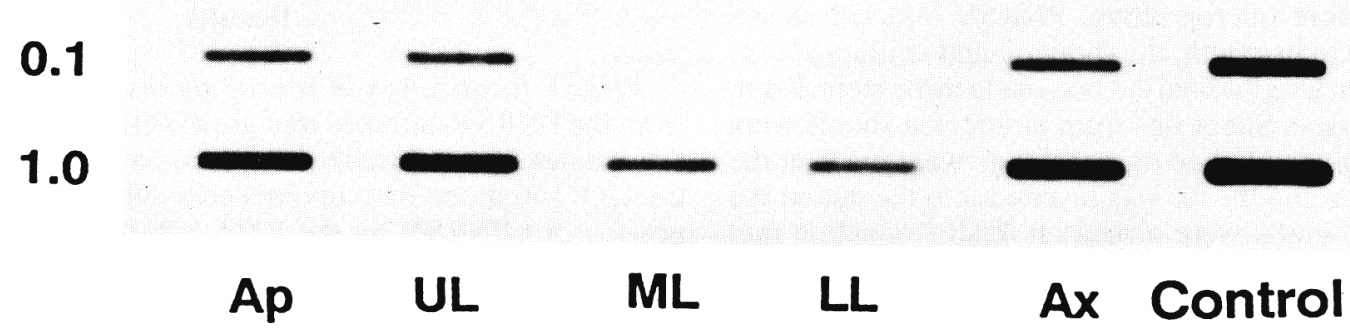

Fig. 1. RNA slot-blot hybridization showing localization of PNRSV in a peach shoot culture. Ap, apical growing tip; UL, lowest folded leaf; ML, middle leaf, LL, lowest unfolded leaf; Ax, axillary shoot tips. Numbers at left indicate amount of sample applied to slot in milligrams fresh weight of leaf tissue. Control is total RNA isolated from PNRSV (PE5 strain)-inoculated Chenopodium quinoa.

\section{Discussion}

Peach shoot cultures maintained detectable levels of PNRSV for several months in vitro, including a period of cold treatment, suggesting that they are a suitable source of PNRSV for in vitro inoculations. Comparison of virus concentrations in younger and older leaves indicated that careful attention to the selection of leaves for sampling will be important in future assays. Although the time-course study of younger and older leaves indicated less variation of virus concentration within a shoot over time in older than in younger leaves, we selected young leaves for sampling in our grafting experiments, since the virus was less easily detectable in older leaves.

A significant fluctuation of virus concentration occurred in

\section{Younger Leaves}

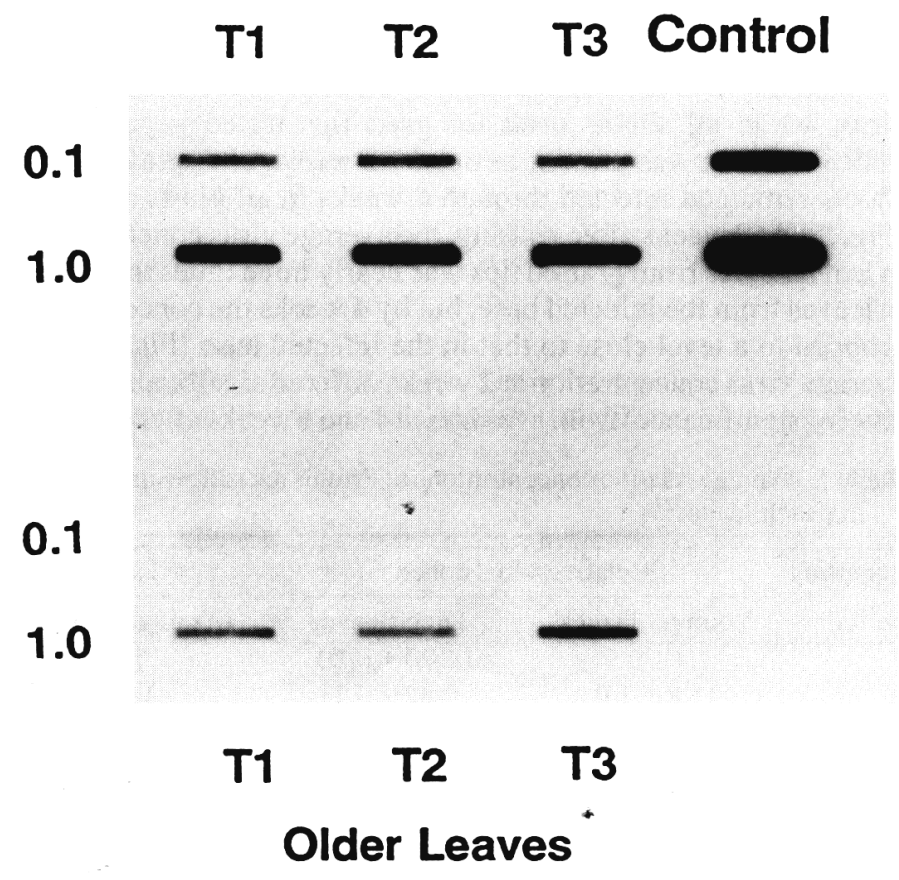

Fig. 2. RNA slot-blot hybridization showing PNRSV concentrations in younger (lowest folded) and older (from the middle of the stem) leaf samples taken three times at 2-week intervals from peach shoot cultures. Numbers at left indicate amount of sample applied to slot in milligrams of fresh leaftissue. Control is total RNA isolated from PNRSV (PE5 strain)-inoculated Chenopodium quinoa. many grafts between 2 and 4 weeks after grafting. A peak in virus concentration in early stages of infection following mechanical inoculation is a common observation, and virus concentrations can reach levels hundreds of times greater than those found later in chronically-infected leaves (Cuozzo et al., 1988). However, because an increase in virus concentration was observed over a 4week period in younger leaves of shoots, we cannot eliminate factors related to culture conditions as a possible cause of variations in virus concentration.

Tanne et al. (1993) recently adapted in vitro micrografting to speed up virus detection using indicator plants. Stein et al. (1991) transferred PNRSV between peach cultivars by in vitro grafting to provide material for testing heat inactivation methods, but did not describe virus accumulation in inoculated shoots. Our report is the first detailed description of virus transfer by in vitro micrografting. The cRNA probe used in this study is complementary to a region

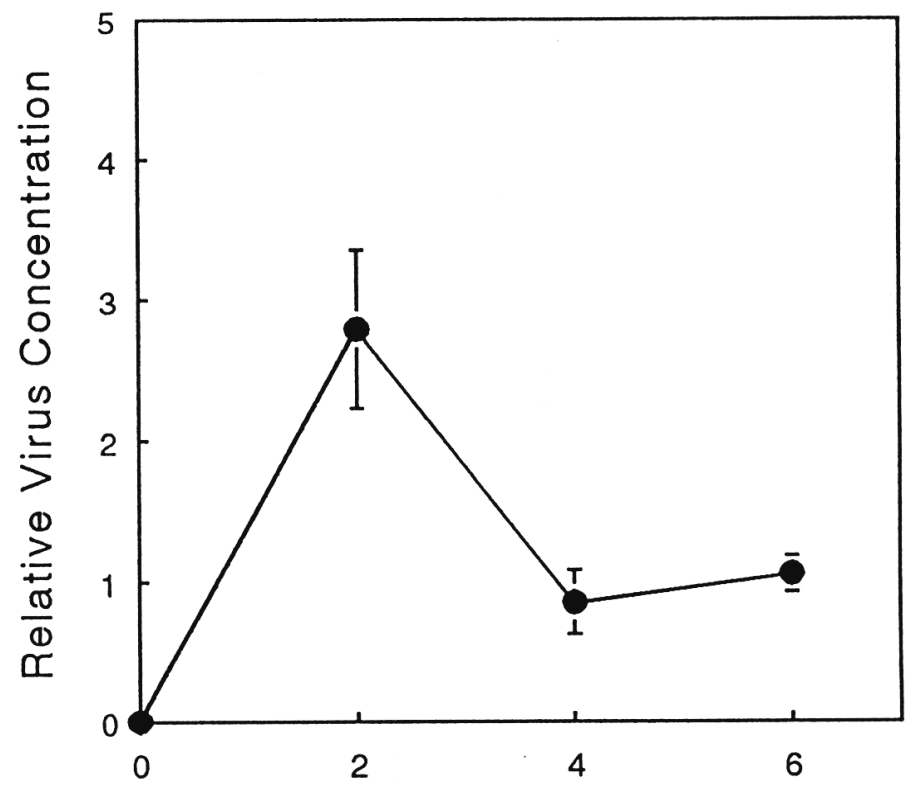

Weeks After Grafting

Fig. 3. Average PNRSV concentrations (relative to the infected base) in 12 initially uninfected peach shoot tips at different sampling periods after micrografting to PNRSV-infected decapitated peach shoots. Error bars represent the standard errors among three replications of four grafts each. 
of PNRSV RNA 3 which spans a portion of the putative coat protein gene (ORF 2), as well the 5' open reading frame (ORF 1) of RNA 3 (Hammond and Crosslin, 1995). We have since synthesized a probe containing only the part of the sequence complementary to ORF 1 , which should therefore detect virus infection and not endogenous expression of coat protein RNA in transgenic peach. Grafting uninfected shoot tips onto PNRSV-infected decapitated shoots had a high rate of success and PNRSV was consistently detected by RNA hybridization in previously uninfected tips by 2 weeks after grafting. We suggest that assaying PNRSV by RNA hybridization after inoculation by in vitro micrografting is a suitable method for rapid, year-round screening for resistance in transgenic and conventionally produced peach cultivars.

\section{Literature Cited}

Alskief, J. 1977. Sur le greffage in vitro d'apex surdes plantules decapitees de pecher (Prunus persica L. Batsch.) C.R. Acad. Sci. Paris Ser. D 284:2499-2502.

Crosslin, J.M., R.W. Hammond, and F.A. Hammerschlag. 1992. Detection of Prunus necrotic ringspot virus serotypes in herbaceous and Prunus hosts with a complementary RNA probe. Plant Dis. 76:11321136.

Cuozzo, M., K.M. O’Connell, W. Kaniewski, R.-X. Fang, N.-H. Chua, and N.E. Turner. 1988. Viral protection in transgenic tobacco plants expressing the cucumber mosaic virus coat protein or its antisense RNA. Bio/Technology 6549-557.

Hammerschlag, F.A. 1982. Factors affecting establishment and growth of peach shoots in vitro. HortScience 17:85-86.

Hammond, R.W. and J.M. Crosslin. 1995. The complete nucleotide sequence of RNA 3 of a peach isolate of Prunus necrotic ringspot virus. Virology 208:349-353.

Hull, R. and J.W. Davies. 1992. Approaches to nonconventional control of plant virus diseases. Crit. Rev. Plant Sci. 11:17-33.

Loebenstein, G., A. Gera, A. Barnett, S. Shabhtai, and J. Cohen. 1980. Effect of 2,4-dichlorophenoxyacetic acid on multiplication of tobacco mosaic virus in protoplasts from local-lesion and systemic-responding tobaccos. Virology 100:110-115.

Mink, G.I. 1992. Prunus necrotic ringspot virus, p. 335-356. In: E.J. Kumar, H.S. Chaube, U.S. Singh, A.N. Mukhopadhyay (eds.). Plant diseases of international importance. Vol. 3. Diseases of fruit crops. Prentice Hall, Englewood Cliffs, N.J.

Mosella, C.L., P.A. Signoret, and R. Jonard. 1980. Sur la mise au point de techniques de microgreffage d'apex en vue de l'elimination de deux types de particules virales chez le Pecher (Prunus persica Batsch). C.R. Acad, Sci. Paris Ser. D 289: 1335-1338.

Murashige, T., W.P. Bitters, T.S. Rangan, E.M. Nauer, C.N. Roistacher, and P.B. Holliday. 1972. A technique of shoot apex grafting and its utilization towards recovering virus-free Citrus clones. HortScience 7:118-119.

Murashige, T. and F. Skoog. 1962. A revised medium for rapid growth and bioassays with tobacco tissue cultures. Physiol. Plant. 15:473-497.

Navarro, L., G. Llacer, M. Cambra, J.M. Arregui, and J. Juarez. 1982. Shoot-tip grafting in vitro for elimination of viruses in peach plants (Prunus persica Batsch). Acta Hort. 130:185-191.

Nyland, G., R.M. Gilmer, and J.D. Moore, 1974. Prunus ringspot group, p. 104-1 32. In: Virus diseases and noninfectious disorders of stone fruits in North America. U.S. Dept. of Agr. Hdbk. No. 437.

Pine, T.S. 1964. Influence of necrotic ringspot virus on growth and yield of peach trees. Phytopathology 54:604-605.

Reinert, R.A. 1966. Virus activity and growth of infected and healthy callus tissues of Nicotiana tabacum grown in vitro. Phytopathology 56:731-733.

Schmitt, R.A., H. Williams, and G. Nyland. 1977. Virus diseases can decrease peach yields. Cling Peach Quarterly 13:17-19.

Scott, SW., O.W. Barnett, and R.B. Baker. 1986. Some facets of the ecology of Prunus necrotic ringspot virus in peach trees in South Carolina. Proc. Workshop Epidem; Plant Virus Dis., Orlando, Fla. p. 43.

Stein, A., S. Spiegel, G. Faingersh, and S. Levy. 1991. Responses of micropropagated peach cultivars to thermotherapy for the elimination of Prunus necrotic ringspot virus. Ann. Applied Biol. 119:265-271.

Tanne, E., N. Shlamovitz, and P. Spiegel-Roy. 1993. Rapidly diagnosing grapevine corky-bark by in vitro micrografting. HortScience 28:667-668. Topchiiska, M.L. 1982. Effect of Prunus necrotic ringspot virus (PNRV) and prune dwarf virus (PDV) on some biological properties of peach. Acta Hort. 130:307-312.

van Dun, C.M.P., B. Overduin, L. van Vloten-Doting, and J.F. Bol. 1988. Transgenic tobacco expressing tobacco streak virus or mutated alfalfa mosaic virus coat protein does not cross-protect against alfalfa mosaic virus infection. Virology 164:383-389.

Uyemoto, J.K., W.K. Asai, and C.F. Luhn. 1992. Ilarviruses: evidence for rapid spread and effects on vegetative growth and fruit yields of peach trees. Plant Dis. 76:71-74.

Wells, J.M., H.C. Kirkpatrick, and C.L. Parish. 1986. Symptomatology and incidence of Prunus necrotic ringspot virus in peach orchards in Georgia. Plant Dis. 70:444-447.

Wilson, T.M.A. 1993. Strategies to protect crop plants against viruses: pathogen-derived resistance blossoms. Proc. Natl. Acad. Sci. USA 90:3134-3141. 